\title{
INDOMETHACIN IN IN-PATIENT TREATMENT OF RHEUMATOID ARTHRITIS
}

\author{
BY \\ D. A. PITKEAThLY, N. R. BANERJEE, R. HARRIS, and J. SHARP \\ Devonshire Royal Hospital, Buxton
}

Indomethacin has been used in the treatment of rheumatic disease for over 3 years. Preliminary reports of the effectiveness of the drug were encouraging (Rothermich, 1963; Norcross, 1963) Katz, Pearson, and Kennedy (1963) also found the drug to be beneficial but treatment had to be discontinued in over 20 per cent. of patients because of side-effects. Hart and Boardman (1963) showed that indomethacin produced a measurable reduction in swelling of the proximal interphalangeal joints in patients with rheumatoid arthritis and that, when a placebo and the drug were used alternately, significant rebound effects commonly occurred with the commencement of placebo treatment. Side-effects principally headache, dizziness, dyspepsia, and mental disturbances, were frequent being observed in over 50 per cent. of patients treated with a dose exceeding $200 \mathrm{mg}$. A trial of the drug by Wanka, Jones, Wood, and Dixon (1964) showed that indomethacin was effective when compared with a placebo, and a comparative trial against phenylbutazone by Percy, Stephenson, and Thompson (1964) showed that $200 \mathrm{mg}$. indomethacin was approximately equivalent to $300 \mathrm{mg}$. phenylbutazone daily, although a decidedly higher incidence of sideeffects occurred with indomethacin.

During this period of development of the drug it was supplied in tablet form and the doses used ranged from 150 to $400 \mathrm{mg}$. daily. Wanka and others (1964), using this preparation and range of dose, reported one case of intestinal haemorrhage and one of perforated gastric ulcer. Lövgren and Allander (1964) used a similar dosage in eighteen patients with rheumatoid arthritis, six of whom had a previous history of peptic ulcer but had negative barium meals immediately before treatment; five patients developed peptic ulcers, two of these having no previous history, and three of the five had severe bleeding.
During the past 2 years indomethacin has been supplied in capsule form and the manufacturers have recommended an initial dose of $50 \mathrm{mg}$. daily, gradually increasing to a maximum of $150 \mathrm{mg}$. The incidence of side-effects was stated to have fallen from 50 to 10-30 per cent. of all treated patients (Today's Drugs, 1964) as a result of using capsules and more conservative dosage, and Clark (1964) reported satisfactory improvement in many patients of a large group with rheumatoid arthritis using this scale of dosage. Recently Hart and Boardman (1965) have compared $75 \mathrm{mg}$. indomethacin daily with $300 \mathrm{mg}$. phenylbutazone daily, in out-patients with rheumatoid arthritis. A double-blind crossover trial was carried out, each drug being given for a period of 28 days. No significant differences were found in the relief of symptoms although there was a greater reduction of morning stiffness with phenylbutazone. There were no significant differences in strength of grip or in improvement in ring sizes of proximal interphalangeal joints, but indomethacin tended to have a greater effect on the latter. The preference of patients was in favour of phenylbutazone. The incidence of side-effects of indomethacin in this short-term trial are not stated, but in longterm studies on patients with rheumatoid arthritis, osteo-arthritis, and ankylosing spondylitis, the authors found that 37 per cent. of the patients developed side-effects of drug treatment.

The present study has been carried out to evaluate indomethacin in a dose of 50 to $100 \mathrm{mg}$. in the inpatient treatment of patients with rheumatoid arthritis. Salicylates are currently the mainstay of drug therapy while the patient is being treated with rest in bed and splintage followed by graded exercises. It was our aim to decide if indomethacin could effectively replace salicylates under these circumstances.

Hajnal, Sharp, and Popert (1959) have drawn 
attention to the considerable effect of "spontaneous improvement" in hospitalized patients. In addition to rest in bed and splintage, other features such as increasing familiarity with hospital envirenment and in the case of strength of grip, practice in the use of the apparatus, contribute to the improvement shown. This must be dissociated from the effect of drug therapy before the value of a new drug can be assessed.

\section{Patients Studied and Methods Employed}

34 women and eight men with classical and definite rheumatoid arthritis (1958 A.R.A. Criteria-Ropes, Bennett, Cobb, Jacox, and Jessar, 1959) were studied. Before entering the trial each patient spent one week settling into the hospital routine. During this period analgesia was provided by soluble aspirin and was maintained at the pre-admission dose provided that this did not exceed $4 \mathrm{~g}$. daily. If the patient was already on corticosteroids, the dose was maintained at the preadmission level during the first week and throughout the trial.

Patients were excluded from the study if they had known peptic ulceration or severe dyspepsia or were intolerant of aspirin, or if the grip test could not be adequately performed by reason of severe anatomical deformity of the hands or if the strength of grip exceeded $300 \mathrm{~mm}$. $\mathrm{Hg}$.

The patients were allotted alternately to indomethacin or soluble aspirin on entry. The first drug was given for a 2-week period and then the other drug was administered for a further 2 weeks, so that half the patients received indomethacin followed by soluble aspirin, and the other half received soluble aspirin followed by indomethacin. The soluble aspirin was specially coloured and flavoured and the patients were unaware of the identity of the tablets. It was given in a dose of $4 \mathrm{~g}$. daily throughout the 2-week period. Indomethacin was given in a dose of $25 \mathrm{mg}$. twice daily for 2 days, followed by $25 \mathrm{mg}$. three times daily for 6 days and then $25 \mathrm{mg}$. four times daily for the remaining 6 days.

Of the 42 patients, 38 completed the study. Two patients were withdrawn while taking soluble aspirin, one because of severe deafness and the other on account of repeated vomiting. One patient developed profound dizziness on indomethacin and the drug had to be withdrawn. The fourth patient was given an incorrect dose of indomethacin during the second week of treatment and was therefore excluded from the analysis. Of the remainder, twenty patients had commenced the trial taking soluble aspirin and eighteen patients had started with indomethacin. Five of those starting on soluble aspirin were taking prednisolone with a mean daily dose of $9 \mathrm{mg}$; seven of those starting on indomethacin were taking prednisolone with a mean daily dose of $10 \mathrm{mg}$.
Clinical Assessment.-Assessments were carried out on the first day of the trial and thereafter at weekly intervals until the completion of the study. As far as possible the patients were assessed at the same time of day throughout and the daily physiotherapy was not given until the assessments had been made. Strength of grip of both hands were recorded weekly. Swelling of the proximal interphalangeal joints was measured using jeweller's rings. These rings were labelled from $A$ to $Z$ with intermediate half-sizes; the diameter of size $A$ was 0.476 in. and the increase in diameter from size A to B was 0.015 in. The patients were questioned concerning headache, dizziness, and dyspepsia, and any other side-effects were noted. At the end of the study the patients' preference for one drug or the other was recorded.

\section{Analysis of Results}

The mean strength of grip at the commencement of the study and at weekly intervals throughout the trial was calculated for each series of patients (Table I).

TABLE I

MEAN VALUES FOR WEEKLY ESTIMATIONS OF STRENGTH OF GRIP (mm. Hg) FOR PATIENTS STARTING ON SOLUBLE ASPIRIN AND INDOMETHACIN

\begin{tabular}{|c|c|c|c|}
\hline \multicolumn{2}{|c|}{ Starting Drug } & Soluble Aspirin & Indomethacin \\
\hline \multicolumn{2}{|c|}{ No. of Cases } & 20 & 18 \\
\hline \multirow{3}{*}{$\begin{array}{c}\text { Grip } \\
\text { (mm. } \\
\mathbf{H g})\end{array}$} & Initial & $145 \cdot 65$ & $159 \cdot 28$ \\
\hline & $\begin{array}{l}\text { Week } 1 \\
\text { Week } 2\end{array}$ & $\left.\begin{array}{l}163 \cdot 90 \\
173 \cdot 60\end{array}\right\}$ Aspirin & $\left.\begin{array}{l}194 \cdot 11 \\
194 \cdot 50\end{array}\right\}$ Indomethacin \\
\hline & $\begin{array}{l}\text { Week } 3 \\
\text { Week } 4\end{array}$ & $\left.\begin{array}{l}183 \cdot 80 \\
188 \cdot 30\end{array}\right\}$ Indomethacin & $\left.\begin{array}{l}199 \cdot 17 \\
202 \cdot 06\end{array}\right\}$ Aspirin \\
\hline
\end{tabular}

Improvement was most marked during the first week of treatment with both drugs and in this week the average improvement was almost twice as great in those starting on indomethacin as in those starting on soluble aspirin. In the second week the indomethacin group-although then on a slightly higher dosage, having changed from $25 \mathrm{mg}$. three times daily to $25 \mathrm{mg}$. four times daily-showed on average no improvement in mean strength of grip but the value in the soluble aspirin group continued to improve, so that after 2 weeks the difference had narrowed considerably. During the second half of the study both groups showed some further average improvement, which was again more steady in those starting on aspirin, who were now on indomethacin; over the whole of the second fortnight those now on soluble aspirin showed only half the improvement of $\stackrel{\oplus}{?}$ the other group. The total improvement after 47 weeks was virtually identical in the two groups.

In order to exclude at least part of the random variations known to play a considerable role in 
patients suffering from rheumatoid arthritis, the further statistical analysis shown in Table II was based on the means of the two assessments of each patient after weeks 1 and 2 and after weeks 3 and 4 , when the patients had been under treatment with each drug for a sufficient period of time for it to have influence on the test results. The analysis was done as recommended for cross-over trials in the appendix to a paper by Hajnal, Sharp, and Popert (1959). This method allows the measurement not only of the difference in the effect of the two drugs but also of the effect of "spontaneous improvement" which comprises the effect of all other treatment and environmental factors, including practice in the use of the apparatus for the grip test.

As the range of mean strength of grip varied considerably in our patients-from as low as $72 \mathrm{~mm}$. Hg to $300 \mathrm{~mm}$. $\mathrm{Hg}$ (the highest registered by our apparatus) - it was felt that the proportionate difference between the mean grip values on the two drugs was more meaningful than the numerical difference; the proportions were taken in percentages of the higher of the two values compared. The relevant statistical calculations were made from both numerical and proportionate differences.

It will be seen (Table II) that spontaneous improvement was about twice as great as the drug effect and statistically far more significant whether the calculation was done numerically or proportionately; but the drug effect, in favour of indomethacin, just reached 5 per cent. significance in the proportionate calculation. [If we had based our calculation on the difference between initial assessment and the end of week 2 and between the ends of weeks 2 and 4, i.e. without attempt to exclude random variations, the drug effect would have worked out numerically slighter larger $(7.2 \mathrm{~mm}$. $\mathrm{Hg})$ but statistically not significant, and proportionately it would have been smaller and still less significant, and the effect of "spontaneous improvement" would have about doubled, with ample statistical significance.]
Ring sizes were assessed in similar fashion. We did not work out actual ring sizes but only the improvements from week to week as shown in Table III. It will be seen that the largest mean improvement with both drugs occurred in the first week but this was not as large in comparison with other weeks as the improvement in grip strength. There was no persistent trend over the 4 weeks; in the first and in the last week of the trial those on indomethacin, and in the second and third week those on aspirin were doing a little better, while the total improvement over the 4 weeks was virtually the same in the two groups.

TABLE III

WEEKLY MEAN IMPROVEMENTS IN RING SIZES FOR PATIENTS STARTING WITH SOLUBLE ASPIRIN AND INDOMETHACIN

\begin{tabular}{|c|c|c|c|}
\hline \multicolumn{2}{|c|}{ Starting Drug } & Soluble Aspirin & Indomethacin \\
\hline \multicolumn{2}{|c|}{ No. of Cases } & 20 & 18 \\
\hline \multirow{3}{*}{$\begin{array}{l}\text { Ring } \\
\text { Sizes }\end{array}$} & $\begin{array}{l}\text { Week } 1 \\
\text { Week } 2\end{array}$ & $\left.\begin{array}{l}4 \cdot 03 \\
3 \cdot 30\end{array}\right\}$ Aspirin & $\left.\begin{array}{l}4 \cdot 72 \\
2 \cdot 25\end{array}\right\}$ Indomethacin \\
\hline & $\begin{array}{l}\text { Week } 3 \\
\text { Week } 4\end{array}$ & $\left.\begin{array}{l}1 \cdot 35 \\
3 \cdot 75\end{array}\right\}$ Indomethacin & $\left.\begin{array}{l}1.89 \\
3.42\end{array}\right\}$ Aspirin \\
\hline & Total & $12 \cdot 43$ & $12 \cdot 28$ \\
\hline
\end{tabular}

On studying the figures it will be apparent that there was no difference between the two drugs. An analysis on lines comparable to that for strength of grip was carried out and confirmed this finding. It also showed that most of the improvement which occurred was attributable to "spontaneous improvement".

Drug Toxicity.-The side-effects encountered during the two treatment periods are shown in Table IV (opposite); included are those which occurred in the four patients who were not considered in the analysis. Headaches were commonly encountered during indomethacin treatment but they were not severe and often subsided after a few days

TABLE II

MEAN STRENGTH OF GRIP DURING SOLUBLE ASPIRIN AND INDOMETHACIN TREATMENT PERIODS AND DIFFERENCES BETWEEN THESE VALUES

[INDOMETHACIN RATINGS (A) MINUS SOLUBLE ASPIRIN RATINGS (B)]

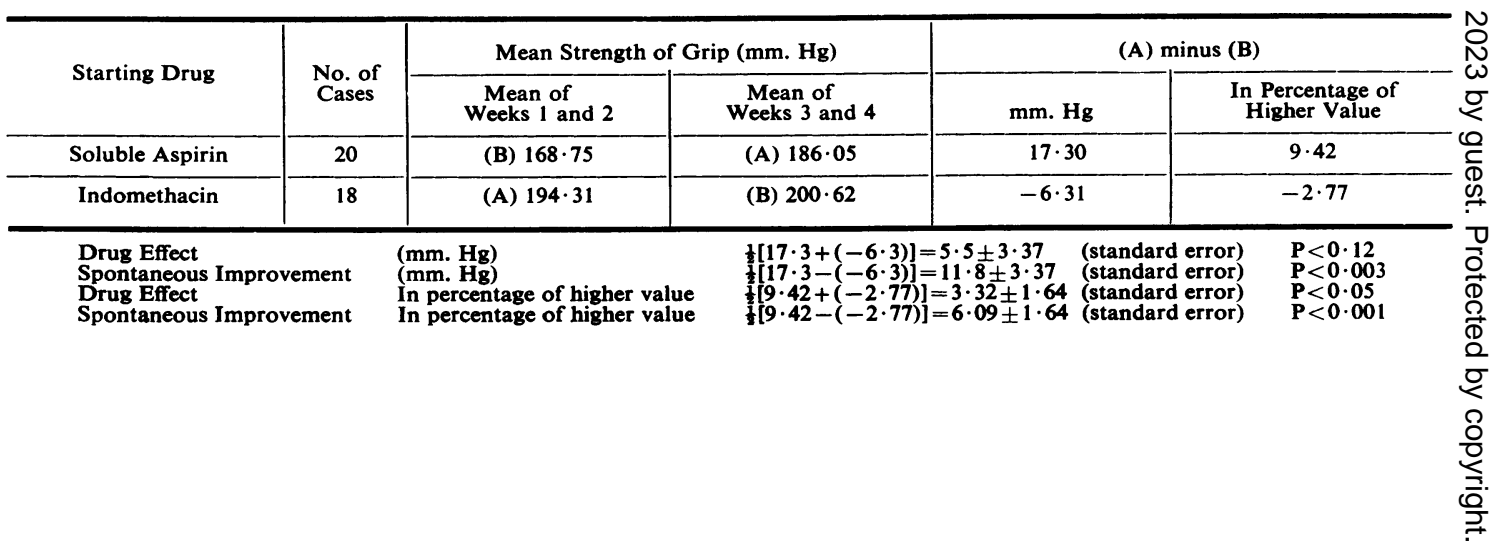


TABLE IV

SIDE-EFFECTS ATTRIBUTABLE TO SOLUBLE ASPIRIN AND INDOMETHACIN IN 42 PATIENTS

\begin{tabular}{c|c|c}
\hline & \multicolumn{2}{|c}{ Drug } \\
\cline { 2 - 3 } Side-effect & Soluble Aspirin & Indomethacin \\
\hline Headache & 10 & 17 \\
Dizziness & 3 & 4 \\
Deafness & 6 & 0 \\
Dyspepsia & 10 & 10 \\
Vomiting & 3 & 1 \\
Diarrhoea & 3 & 0 \\
Rash & 0 & 1 \\
Sweating & 1 & 1 \\
\hline
\end{tabular}

although the indomethacin was continued. The high incidence of headaches reported during soluble aspirin treatment is surprising and in only one instance was it possible for the headache to have carried over from indomethacin to soluble aspirin treatment periods. Direct questioning of the patients regarding headache may have been responsible for this finding. Severe dizziness occurred in only one patient during indomethacin treatment and necessitated withdrawal from the trial. Gastrointestinal disturbances were more troublesome during soluble aspirin treatment and caused the withdrawal of one patient from the study. A slight rash developed on the feet and ankles of one patient while on indomethacin but this did not interfere with the continuation of the study.

Patient Preference.-This is shown in Table V. All three patients who were withdrawn from the trial because of severe side-effects on one drug completed 2 weeks of treatment on the other drug and are shown as preferring that drug.

TABLE V

PATIENT PREFERENCE

\begin{tabular}{|c|c|}
\hline Preference & No. of Cases \\
\hline $\begin{array}{l}\text { For Soluble Aspirin } \\
\text { For Indomethacin } \\
\text { None }\end{array}$ & $\begin{array}{r}21 \\
13 \\
7\end{array}$ \\
\hline Total & 41 \\
\hline
\end{tabular}

\section{Discussion}

The anti-inflammatory action of indomethacin has been demonstrated convincingly under experimental conditions. Winter, Risley, and Nuss (1963) showed that the drug had a powerful effect in inhibiting granuloma formation in rats. In addition, inflammatory oedema induced by carrageenin was suppressed. Boris and Stevenson (1965) found that indomethacin was the most powerful of a group of five anti-inflammatory agents in inhibiting the on inflammatory reaction induced by carrageenin in rats, the others being flufenamic acid, mefenamic $\stackrel{\vec{\sim}}{\rightarrow}$ acid, oxyphenylbutazone, and phenylbutazone in order of decreasing potency. Under clinical con- $\frac{\bar{\sigma}}{\vec{*}}$ ditions, Hart and Boardman (1963) confirmed this $\frac{\bar{p}}{7}$ anti-inflammatory action using $150-300 \mathrm{mg}$. of the $\stackrel{\mathbb{Q}}{\Omega}$ drug daily. In view of the high incidence of side- क्ष effects with this range of dose we wished to study the effect of indomethacin in a dose not exceeding 100 . mg. daily in the in-patient treatment of rheumatoid $\vec{\omega}$ arthritis and to compare it with soluble aspirin in a dose commonly used in these patients. Studies had $\frac{\varrho}{2}$ already been carried out by Hart and Boardman is (1965) and Thompson and Percy (1966) and the drug on was found to have considerable therapeutic value in patients with a variety of rheumatic diseases.

In recent years salicylates have been shown con- 을 vincingly to have anti-inflammatory properties in experimental animals. Spector and Willoughby $\overleftarrow{c}$ (1963) showed that systemic sodium salicylate has an inhibitory effect on the volume of exudate in turpen- $\vec{\bullet}$ tine-induced pleurisy in the rat and causes a non- $\triangle$ specific suppression of the action of many substances 0 that increase vascular permeability. Kelemen (1963) studied acute inflammatory oedema in rats using $1^{131}$ serum albumin. He considered that there were two components to the inflammatory response. One was inflammatory swelling which was diminished by salicylate. The other, a possible tissue component, preceded visible swelling, persisted after the oedema had disappeared, and was unaffected by salicylate. In view of this work on salicylates in experimentally-induced inflammation, it must be borne in mind that doses of $4 \mathrm{~g}$. daily in patients with rheumatoid arthritis may have anti-inflammatory activity of the same order of magnitude as that $\delta$ shown by indomethacin in low dosage.

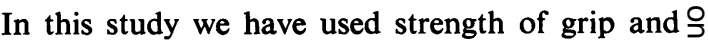
improvement in swelling of the proximal inter- $\rightarrow$ phalangeal joints measured by jeweller's rings to을 assess the weekly improvement throughout the trial N period. Analysis of mean strength of grip during periods of treatment with soluble aspirin and 0 indomethacin has shown that drug effect was $\omega$ approximately one half of the effect attributable to spontaneous improvement. It has also been showno that indomethacin had a greater effect than aspirin $\mathbb{D}$ in improving strength of grip and that this difference ${ }^{?}$ was just significant at the 5 per cent. level. On the other hand, there was no difference between the two drugs in their effect in reducing swelling of the $\stackrel{P}{P}$ proximal interphalangeal joints and most of the $\stackrel{\mathbb{Q}}{\stackrel{Q}{2}}$ 
improvement which occurred was the result of spontaneous improvement.

There was a greater preference of patients for soluble aspirin than for indomethacin in this trial. The incidence of headache during soluble aspirin treatment was surprisingly high, so that the patient preference can hardly be due to indomethacin headaches unless these were qualitatively different from the headaches reported during aspirin treatment. Greater pain relief from aspirin in the dosage used may have been important. Hart and Boardman (1963) stated that indomethacin had no analgesic action in the mouse or rat using methods then in use. The manufacturers claim, as a result of controlled clinical studies, that $50 \mathrm{mg}$. indomethacin is equal in analgesic effect to $600 \mathrm{mg}$. acetylsalicylic acid. If this is so, then the analgesia produced by aspirin in this study was much greater than that produced by indomethacin.

The high incidence of side-effects of indomethacin reported in the literature has made physicians cautious. Headache and dyspepsia were still fairly frequent in this study despite the low dosage employed and the slow build-up of the drug. On the other hand, the incidence of side-effects except headache differed little from that occurring with $4 \mathrm{~g}$. soluble aspirin daily. There is little doubt that sideeffects would have been reported less frequently with both drugs if patients had not been asked about specific symptoms. No serious complications such as gastro intestinal haemorrhage occurred, but the trial was of short duration and patients with severe dyspepsia or known peptic ulcer were not admitted to it. It is to be noted that, in the studies of Hart and Boardman (1965) and Thompson and Percy (1966), cases of neurological disturbance and gastrointestinal bleeding were reported and that these side-effects could present after many months of treatment.

\section{Summary}

A cross-over trial of indomethacin and soluble aspirin has been conducted in in-patients with rheumatoid arthritis. The indomethacin was increased from 50 to $100 \mathrm{mg}$. during the treatment period, but the dose of soluble aspirin was maintained at $\mathbf{4} \mathrm{g}$. daily.

A method of analysis has been used which dissociates drug effect from other factors which may lead to the improvement with time usually observed in hospitalized patients regardless of medication. This has re-emphasized the important contribution of these factors.
Comparison of the two drugs has shown that $\frac{2}{3}$ strength of grip improved to a greater extent during $\square$ indomethacin treatment and that this result was just ${ }^{\text {?. }}$. significant at the 5 per cent. level. Decrease in $\vec{F}$ swelling of proximal interphalangeal joints was very $\frac{\sqrt{7}}{0}$ similar during treatment with the two drugs but 21 등 patients preferred soluble aspirin, whereas thirteen $\frac{\bar{\sigma}}{\bar{c}}$ preferred indomethacin, and the remaining seven had $\underset{\mathbb{D}}{\stackrel{5}{ }}$ no preference.

It is concluded that indomethacin should not replace aspirin in the routine treatment of in-patients $\vec{\circ}$ with rheumatoid arthritis. However some patients appear to do better with indomethacin and it may $\vec{\sigma}$ therefore be useful in selected cases.

We wish to thank Professor J. H. Kellgren for advice and criticism in the preparation of this paper. Miss F. Bier performed the statistical analysis and we are greatly indebted to her.

\section{REFERENCES}

Boris, A., and Stevenson, R. H. (1965). Arch. int. Pharmacodyn., 153, 205.

Clark, G. M. (1964). Arthr. and Rheum., 7, 300.

Hajnal, J., Sharp, J., and Popert, A. J. (1959). Ann." rheum. Dis., 18, 189.

Hart, F. D., and Boardman, P. L. (1963). Brit. med. J., 2, 965.

- - (1965). Ibid., 2, 1281.

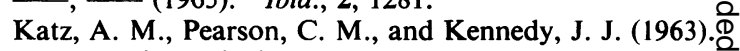
Arthr. and Rheum., 6, 281.

Kelemen, E. (1963). In "Salicylates: An Internationalo Symposium sponsored by the Empire Rheumatism Council with the support of the Nicholas Research Institute, Ltd. Post-graduate Medical School of London, 1962", ed. A. StJ. Dixon, B. K. Martin, M. J. H. Smith, and P. H. N. Wood, p. 148으 Churchill, London.

Lövgren, O., and Allander, E. (1964). Brit. med. J., 1, 118.

Norcross, B. M. (1963). Arthr. and Rheum., 6, 290.

Percy, J. S., Stephenson, P., and Thompson, M. (1964).윽 Ann. rheum. Dis., 23, 226.

Ropes, M. W., Bennett, G. A., Cobb, S., Jacox, R., ando Jessar, R. A. (1959). Ibid., 18, 49.

Rothermich, N. O. (1963). Arthr. and Rheum., 6, 295. N

Spector, W. G., and Willoughby, D. A. (1963). In "Salicylates: An International Symposium spon-O sored by The Empire Rheumatism Council withw the support of the Nicholas Research Institute Ltd., Post-graduate Medical School of London 6 1962", ed. A. St.J. Dixon, B. K. Martin, M. J. H Smith, and P. H. N. Wood, p. 141. Churchill, London.

Thompson, M., and Percy, J. S. (1966). Brit. med. J., $1 \frac{0}{0}$ 80.

Today's Drugs: Indomethacin (1964). Ibid., 2, 429. 
Wanka, J., Jones, L. I., Wood, P. H. N., and Dixon, A. St.J. (1964). Ann. rheum. Dis., 23, 218.

Winter, C. A., Risley, E. A., and Nuss, G. W. (1963). Fed. Proc., 22, 543.

\section{L'indométhacine dans le traitement hospitalier del'arthrite rhumatismale}

\section{RÉSUMÉ}

On procéda à un essai cross-over de l'indométhacine et de l'aspirine soluble chez des malades hospitalisés, atteints d'arthrite rhumatismale. La dose d'indométhacine fut augmentée de $50 \mathrm{mg}$. à $100 \mathrm{mg}$. pendant la période de tıaitement, mais la dose d'aspirine soluble fut maintenue à $4 \mathrm{~g}$. par jour.

On appliqua une méthode d'analyse qui permit de dissocier l'effet du médicament de celui des autres facteurs qui à l'hôpital ramènent l'amélioration indépendamment de la médication employée. A cette occasion on souligne l'importance de ces facteurs.

La comparaison de ces deux médicaments montra que la force de la main s'améliorait plus au cours du traitement par l'indométhacine et que ce résultat était exactement dans les limites de signification de 5 pour cent. La diminution du gonflement des articulations interphalangiennes proximales fut très similaire pendant le traitement par le deux médicaments, mais 21 malades préférèrent l'aspirine soluble, 13 malades préférèrent l'indométhacine et les autres n'indiquèrent aucune préférence.

On conclut que l'indométhacine ne doit pas remplacer l'aspirine dans le traitement régulier à l'hôpital des malades atteints d'arthrite rhumatismale. Toutefois, certains malades semblent bénéficier de l'indométhacine et on peut la trouver utile dans des cas particuliers.

La indometacina en el tratamiento hospitalario de la artritis $\stackrel{\overline{\vec{N}}}{\stackrel{\vec{N}}{ }}$ reumatoide

\section{Sumario}

Se compararon, por el método de cross-over, la indo- $\frac{\omega^{2}}{\partial}$ metacina y la aspirina soluble en enfermos hospitalizados $\stackrel{\Phi}{\mathcal{D}}$ con artritis reumatoide. Durante el período de tratamiento la dosis de indometacina fué aumentada de $50 \mathrm{mg}$. a $100 \mathrm{cs}$ mg., pero la dosis diaria de aspirina soluble se mantuvo $\vec{\circ}$ a $4 \mathrm{~g}$.

El método de análisis aplicado aquí permitió disociar $\overrightarrow{\vec{H}}$ los efectos del medicamento de otros factores que con- $\omega$ ducen a una mejoría en enfermos hospitalizados independientemente de la medicación. Se subraya la importancia $\bar{\alpha}$ de estos factores.

La comparación de estos medicamentos reveló que la or fuerza de la mano aumentó más durante el tratamiento con indometacina y que este resultado se encontró $\omega_{\omega}$ exactamente dentro de los límites de confianza del 5 por $\AA$ ciento. La reducción de la hinchazón de las articulaciones interfalangianas proximales fué muy similar durante el $\lrcorner$ tratamiento con ambos medicamentos, pero 21 enfermos prefirieron la aspirina soluble, 13 enfermos la indometacina y los demás no indicaron prefrencia alguna.

Se concluye que la indometacina no debe sustituir la $\vec{\bullet}$ aspirina en el tratamiento hospitalario habitual de enfermos con artritis reumatoide. Sin embargo, ciertos enfermos parecen responder mejor con indometacina y su empleo puede ser util en casos particulares. 